\section{Ghrelinets historie}

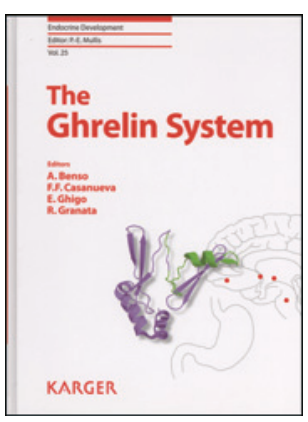

Andrea Benso, Felipe F. Casanueva,

Ezio Ghigo et al, red.

The ghrelin system

171 s, tab, ill. Basel: Karger, 2013.

Pris CHF 180

ISBN 978-3-8055-9908-5

Først var der en reseptor ... Oppdagelsen av hormonet ghrelin i 1999 er et eksempel på «revers farmakologi» - først fant man reseptoren GHS-R1, deretter en rekke småmolekylære farmakologiske substanser som virket på denne reseptoren. Så, etter intens og spennende leting gjennom lang tid, fant en japansk forskergruppe, ledet av Masayasu Kojima og Kenji Kangawa, reseptorenes endogene ligand ghrelin. Peptidet ble funnet uttrykt i celler - ikke i hypothalamus eller andre deler av sentralnervesystemet som man hadde ventet, men helt uventet i magesekken!

I denne boken fortelles historien om ghrelinsystemet frem til i dag på en engasjerende, spennende og lettlest måte. De 16 kapitlene, med ulike forfattere, spenner fra biokjemi via fysiologi, patofysiologi og farmakologi til mulige kliniske anvendelser. Ghrelin har vist seg å ha en rekke effekter i tillegg til stimulering av veksthormonsekresjonen og appetitten. Hormonet virker inn på flere andre nevroendokrine og metabolske akser og har ikke minst viktige effekter på insulinsekresjonen og glukosestoffskiftet. Svært interessant er alle reguleringsmekanismene og mulige angrepspunkter for farmakologisk manipulasjon av systemet: Det 28 aminosyrer lange polypeptidet må acetyleres før det er aktivt - derved er både reguleringsenzymet og den uacetylerte formen mulige farmakologiske mål. I den intense jakten på farmakologiske løsninger på fedme- og diabetesepidemien er det naturlig at ghrelin, som det eneste kjente appetittøkende hormonet, er en attraktiv kandidat for farmakologisk forskning.

Selv om teksten er lettlest er nok målgruppen fagfolk med mer enn middels interesse for appetittregulering og nevroendokrinologiske reguleringsmekanismer. Men med så mangfoldige virkninger som gastrointestinal motilitetsregulering, kardiovaskulær påvirkning og mulige assosiasjoner til anorexia nervosa, kakeksi og diabetes kan nok mange ulike faggrupper finne interessante kapitler her. Med god og enkel nettilgang til både oversiktsartikler og spesiallitteratur om emnet tror jeg det er de spesielt interesserte som vil kjøpe denne ganske kostbare boken.

Layouten er også ganske kjedelig med bare et par fargeillustrasjoner, mye tekst og for få gode og oversiktlige tabeller og illustrasjoner. Noen av kapitlene skjemmes også av en del forkortelser som ikke forklares, og det kunne godt vært et register over forkortelsene.

\section{Kåre Birkeland}

Avdeling for endokrinologi, sykelig overvekt og forebyggende medisin Oslo universitetssykehus

\section{Dypdykk i glomerulonefritter}

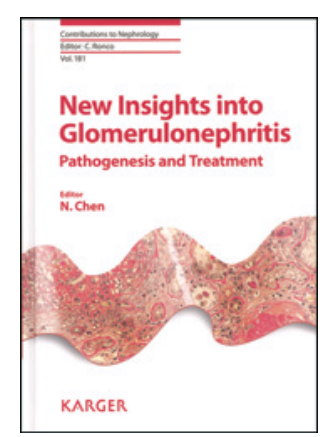

\author{
Nan Chen, red. \\ New insights into glomerulonephritis
}

Pathogenesis and treatment. 256 s, tab, ill.

Basel: Karger, 2013. Pris CHF 198

ISBN 978-3-318-02389-3

Dette er noe for nefrologer og andre med interesse for nyresykdommer. Mye ny viten om patogenese og behandling av glomerulonefritter er kommet til de siste årene, og boken er derfor svært relevant som oppdatering av aktuell kunnskap. Den består av 24 artikler skrevet av noen av verdens fremste forskere i feltet, fra både den vestlige verden og Kina. Alle forfatterne oppgir rikelig med oppdaterte referanser. Redaktørens intensjon er, som hun sier i forordet, todelt: Dette skal være en vitenskapelig oppdatering og en demonstasjon av det vesentlige kinesiske bidraget, som hun håper skal virke som en brobygger mellom kinesisk og vestlig forskning. 13 av de 24 artiklene utgår fra forskningsmiljøer i Shanghai, hvilket er imponerende.

Etter fire innledende artikler følger et dypdykk i IgA-nefropati, fokal segmental glomerulosklerose (FSGS)/Minimal Change (MC), membranøs nefropati (MG), membranoproliferativ glomerulonefritt (MPGN) og til slutt et kapittel om halvmånenefritt. Språket er gjennomgående meget godt. Det er god layout og relativt få, men gode illustrasjoner - ikke mange histologiske bilder, men dette er da heller ingen lærebok. Papiret er førsteklasses. Innbindingen gjør at den ikke passer i lommen, den bør stå på nyreseksjonen som oppslagsbok. Dette er kompakt stoff - tungt å lese fra perm til perm, fullpakket med komplisert patogenese og immunologi.

Jeg vil spesielt fremheve bidraget til Gerald B. Appel, som ikke overraskende er en glimrende oversikt over membranoproliferativ glomerulonefritt, gammel og ny klassifisering, mekanismer og sammenheng med atypisk hemolytisk-uremisk syndrom og alternativ komplementaktivering. En flott figur bidrar til klargjøring av en komplisert patogenese. Det hele avsluttes med en oversikt over moderne behandling av tilstanden.

I en artikkelsamling som denne kan man ikke unngå en del overlapping, men jeg synes egentlig ikke det skjemmer, siden de fleste ikke vil lese den fra a til å, men bruke den som oppslagsbok. Jeg savner et avsnitt om hivassosiert nefritt. Jeg la også merke til at fiskeoljebehandling ikke var drøftet som behandling av IgA-nefritt, noe som fremdeles er kontroversielt. At det fremlegges tall som er mer aktuelle for Kina enn for oss, kan jeg godt leve med.

Patogenese og ikke minst behandling av glomerulonefritter er en utfordring. Dette er et viktig bidrag på et felt som stadig endres, og den må derfor jevnlig oppdateres. Den kan anbefales på det varmeste til alle som er interessert i nyresykdommer.

\section{Aud Høieggen}

Nyremedisinsk avdeling

Medisinsk klinikk

Oslo universitetssykehus 